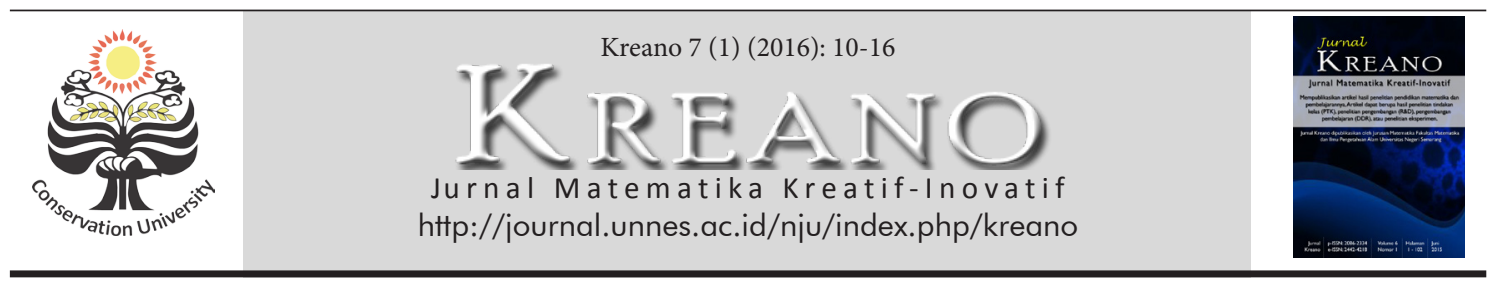

\title{
Pengembangan Soal Matematika Model PISA Level 4, 5, 6 menggunakan Konteks Lampung
}

\author{
Yudi Yunika Putra', Zulkardi², Yusuf Hartono ${ }^{3}$ \\ 'Program Studi Magister Pendidikan Matematika, Unsri, Indonesia \\ Email: yudiyunika@yahoo.co.id \\ DOI: http://dx.doi.org/10.15294/kreano.v7i1.4832 \\ Received : January 2016; Accepted: March 2016; Published: June 2016
}

\begin{abstract}
Abstrak
Menyelesaikan soal matematika menggunakan konteks merupakan suatu cara yang dapat dilakukan untuk membantu menggunakan kemampuan matematikanya dalam kehidupan sehari-hari. Selain itu soal dengan menggunakan konteks akan mempermudah siswa dalam mensituasikan matematika kedalam konteks sehingga akan membantu siswa dalam menggunakan kemampuan literasi dalam menjawab soal, dan dapat menantang pola berpikir matematis siswa.Tujuan dari penelitian ini adalah Menghasilkan soal matematika model PISA menggunakan konteks Lampungyang valid dan praktis. Metode penelitian ini merupakan design research tipe development study. Subjek dalam penelitian ini adalah siswa kelas IX SMP Ar-raihan Bandar Lampung dan SMP Yadika Natar Lampung Selatan yang berumur maksimal 15 tahun. Dalam penelitian ini menghasilkan 15 butir soal PISA menggunakan konteks Lampung yang valid dan praktis serta mempunyai efek potensial terhadap kemampuan literasi matematika siswa.
\end{abstract}

\begin{abstract}
Solve a math problem using a context is a way that can be done by student to help them use their mathematics skills in everyday life. In addition problem using context will facilitate students in modeling the mathematics in context, so that will help the student to use their literacy skills in answering problem, and can challenge students' mathematical thinking patterns. The purpose of this study was to Generate PISA math models using context Lampung valid and practical. This research method is a type of research design development study. Subjects in this study were students of class IX SMP Ar-raihan Bandar Lampung and SMP YadikaNatar Lampung which has aged up to 15 years. The result of this study was 15 items PISA uses Lampung context of a valid and practical and have a potential effect on students' mathematical literacy skills.
\end{abstract}

Keywoords: Konteks Lampung, Literasi Matematika, PISA, Level 4, 5, 6.

\section{PENDAHULUAN}

Literasi matematika merupakan kemampuan seseorang dalam merumuskan, menerapkan, dan menafsirkan matematika dalam berbagai konteks, termasuk kemampuan melakukan penalaran secara matematis dan menggunakan konsep, prosedur, dan fakta untuk menggambarkan, menjelaskan, atau memperkirakan fenomena. Literasi matematika sangat penting karena dapat membantu seseorang untuk memahami peran atau kegunaan matematika di dalam kehidupan sehari-hari sekaligus menggunakannya untuk membuat keputusan-keputusan yang tepat sebagai warga negara yang membangun, peduli, dan berpikir (OECD, 2013).

PISA (Program for International Student Assessment) merupakan sebuah penilaian secara internasional yang diselenggarakan oleh OECD terhadap keterampilan dan kemampuan siswa usia 15 tahun (OECD, 2013; Shiel et al., 2007), usia dimana siswa di sebagian besar Negara mendekati akhir dari wajib belajar (Stacey, 2011). Keterampilan dan kemampuan dalam PISA yang dinilai meliputi matematika, membaca, dan sains (OECD, 2013; Stacey, 2012), pisa pertama dilaksanakan pada tahun 2000 dan kemudian dilaksanakan 3 tahun sekali (Shiel et al., 2007; Kemendikbud, 2011).

Pilihan strategi matematika yang se- 
suai dan representasi seringkali bergantung pada konteks di mana masalah muncul (OECD, 2013). yang mana dalam PISA 2015 konteksnya dibagi menjadi 4 yaitu konteks personal, occupational, sociental, scientifik. dan konteks tersebut berkaitan dengan konten change and relationship, space and shape, quantity, dan uncertainty and data. Serta dalam PISA 2015 terdapat 3 kategori proses yaitu formulate, employ, dan interprete. yang digambarkan dalam model literasi matematika di bawah. (OECD, 2013). Gambar 1. merupakan model penerapan literasi matematika framework PISA 2015.

Sebuah aspek penting dari literasi matematika adalah bahwa matematika terlibat dalam memecahkan masalah yang ditetapkan dalam konteks, konteksnya adalah aspek dunia individu di mana masalah ditempatkan
(OECD, 2013).edangkan pentingnya menyelesaikan soal matematika yang menggunakan konteks, menurut Lutfianto et al., (2013) adalah salah satu cara yang dapat digunakan agar siswa memiliki kemampuan yang dibutuhkan untuk hidup pada abad sekarang. Selain itu soal dengan menggunakan konteks dapat menantang pola berpikir matematis siswa (Kadir \& Masi, 2013). Selanjutnya literasi matematika tidak hanya ada pada saat seseorang memperoleh pendidikan formal saja tetapi pada saat siswa-siswi bersosialisasi atau bermain, mereka pun akan menumbuhkan literasi matematikanya (Hayat \& Yusuf, 2010).

Pada penilaian PISA tahun 2012, diperoleh data bahwa seluruh siswa Indonesia $(98,5 \%)$ sudah mampu mencapai level 3 (NCES, 2013), tetapi masih kesulitan da-

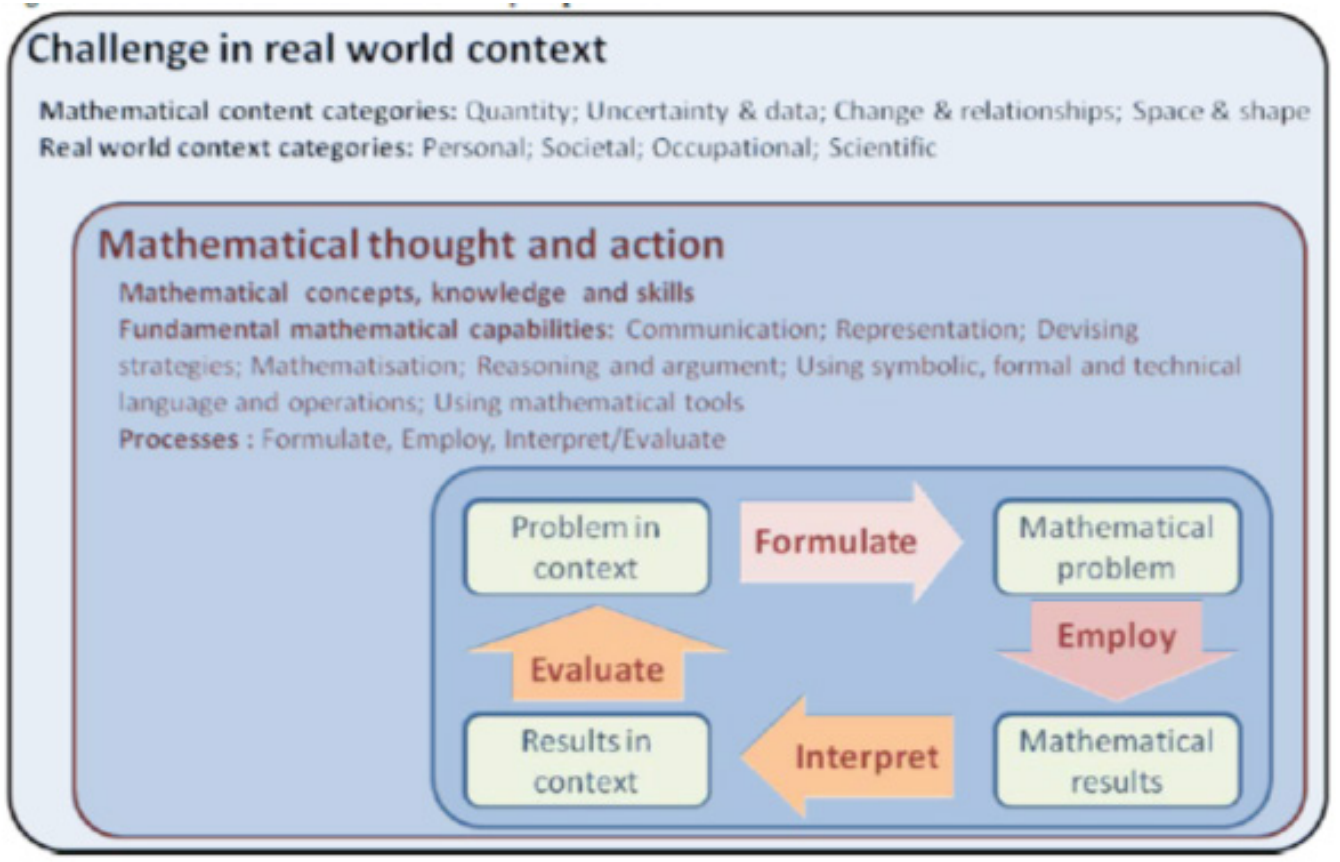

Gambar 1. Model penerapan literasi

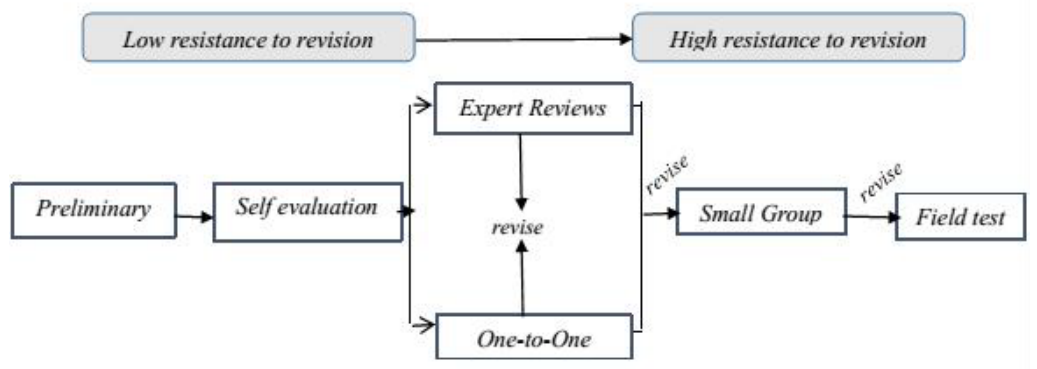

Gambar 2. Alur desain formative evaluation (Tessmer, 1993; Zulkardi,2006) 
lam menyelesaikan soal PISA level 3 ke atas (OECD, 2013). Dari uraian sebelumnya, akan diketahui sejauh mana kemampuan literasi matematika siswa Lampung dalam menyelesaikan soal-soal PISA Level 4, 5, 6 dengan menggunakan konteks Lampung.

\section{METODE}

Artikel ini merupakan sebuah hasil penelitian besar dalam mendapatkan soal matematika model PISA menggunakan konteks Lampung dengan menggunakan dua tahap yaitu tahap persiapan (preliminary) dan tahap prototyping (formative evaluation) yang meliputi one-toone dan expert reviews, small group, dan field test. Gambar 1 merupakan alur desain formative evaluation

Setelah didapatkan soal matematika model PISA menggunakan konteks Lampung yang valid dan praktis selanjutnya subjek menyelesaikan soal PISA level 4, 5, 6 menggunakan konteks Lampung dengan waktu 75 menit. Hasil jawaban siswa di analisis sejauh mana kemampuan literasi matematika siswa Lampung dalam menyelesaikan soal-soal PISA Level 4, 5, 6 dengan menggunakan konteks Lampung. Teknik pengumpulan data dilakukan melalui lembar angket dan hasil tes. Lembar angket untuk mengetahui respon siswa dalam menjawab soal, dan tes untuk mengetahui kemampuan literasi matematika siswa dalam menyelesaikan soal-soal PISA level $4,5,6$. Data yang diperoleh kemudian di analisis secara deskriptif. Berikut contoh soal PISA menggunakan konteks Lampung berturut-turut level 4, 5, dan 6

\section{Petunjuk: Informasi Umum untuk Soal No 1 dan 2}

\section{Konteks: Motif Kain Tapis Lampung}

Gambar 3 adalah gambar tapis Lampung yang merupakan salah satu jenis kerajinan tradisional masyarakat Lampung.
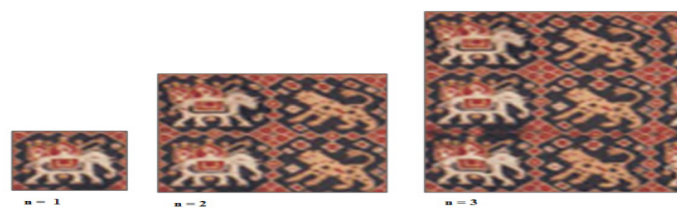

Gambar 3. Desain Kain Lampung
Pada gambar di atas terdapat dua motif, yaitu motif gambar gajah dan motif gambar harimau. Untuk kain dengan luas 81 , dilukis dengan 1 motif gajah, kemudian untuk kain dengan luas 324 dilukis dengan 2 motif gajah dan 2 motif harimau, dan seterusnya mengikuti pola gambar di atas (pola motif).

\section{Soal No 1 Level 4}

Untuk membuat sebuah baju batik orang dewasa rata-rata membutuhkan kain dengan luas 225 117. Jika seorang pengrajin kain tapis mendapat pesanan membuat kain dengan ukuran sebuah baju batik orang dewasa dengan mengikuti pola pada gambar di atas, berapa banyak motif (gajah dan harimau) yang terdapat pada kain tersebut? jelaskan alasanmu!

\section{Soal No 2 Level 5}

Jika seorang pengrajin membuat kain dengan pola $n=75$ mengikuti motif dan pola di atas, desain motif bagaimana yang terbentuk jika dilihat dari desain motif baris terakhir?jelaskan strategimu

(Lingkari salah satu jawaban)

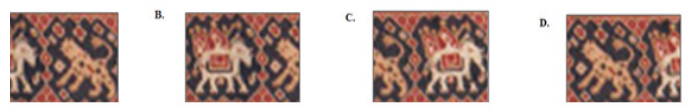

Gambar 4. Konteks: Anak Gunung Krakatau

Anak Gunung Krakatau adalah Gunung berapi yang masih aktif dan berada di Selat Sunda antara pulau Jawa dan pulau Sumatra. Nama Anak Gunung Krakatau berdasarkan dari nama induknya yaitu Gunung Krakatau yang sirna karena letusannya pada tanggal 27 Agustus 1883.

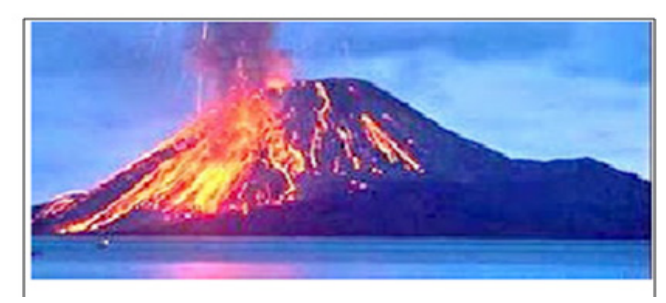

Gambar 5. Anak Gunung Krakatau 


\section{Soal No 3 Level 6}

Gunung Anak Krakatau setiap tahun menjadi lebih tinggi sekitar 20 kaki. Penyebab pertambahan tinggi gunung itu adalah oleh material yang keluar dari lubang lava. Saat ini ketinggian Anak Krakatau mencapai sekitar 230 meter di atas permukaan laut, sementara Gunung Krakatau sebelum meletus memiliki tinggi 813 meter dari permukaan laut. Pada tahun berapa ketinggian Anak Krakatau akan sama dengan induknya sebelum meletus? Jelaskan strategimu (Keterangan: 1 kaki $=0,3048 \mathrm{~m}$ ).

\section{HASIL DAN PEMBAHASAN}

Pada prototipe I menghasilkan 17 soal model PISA Level 4, 5, 6 menggunakan konteks Lampung yang tersebar dalam 3 kontek, 3 proses, dan 3 konten menurut framework PISA. Kemudian prototipe I ini di ujikan pada tahap one-to-one dan expert review. Dari hasil oneto-one sebagian besar komentar siswa mengenai prototipe I adalah gambar konteks yang kurang jelas dan bahasa yang kurang dipahami. Sedangkan selain gambar yang kurang jelas berdasarkan saran ahli pada tahap expert review adalah ada beberapa soal yang tidak menyampaikan ide literasi, soal dalam PISA tidak saling berkaitan, dan ada beberapa soal menggunakan kata yang sulit dipahami.

Berdasarkan komentar/saran expert re- view dan subyek one-to-one didapat 15 soal yang penulis kembangkan memenuhi kriteria valid, tetapi dari 17 soal ada 2 soal yang tidak valid. Selanjutnya hasil revisi pada tahap ini menghasilkan prototipe II yang akan diujikan pada tahap selanjutnya.

Berdasarkan hasil analisis dan komentar/saran siswa pada tahap small group dapat disimpulkan, yaitu (1) soal-soal menggunakan konteks merasa tertantang dalam mengerjakan (2) dalam menjawab soal bisa menggunakan logika (3) soalnya cukup sulit (4) beberapa soal menjebak (5) semua soal dapat diimplementasikan (6) semua kata / kalimat/ gambar/petunjuk/ pertanyaan jelas. Dengan demikian dapat dikatakan bahwa soal-soal tersebut memenuhi karakteristik kepraktisan, tetapi berdasarkan kesan umum siswa (Poin 3 dan poin 4) beberapa soal perlu diperbaiki dengan alasan kepraktisan, kemungkinan siswa merasa sulit dalam mengerjakan disebabkan oleh susunan kata atau kalimat atau sejenisnya yang kurang jelas dalam soal.

Dari hasil uji field test didapatkan $20,45 \%$ dari $330(22 \times 15)$ butir jawaban yang dianalisis yang teridentifikasi sebagai jawaban benar. Dengan sebanyak $43 \%$ dari 110 jawaban $(22 \times 5)$ subjek dapat menyelesaikan soal level 4. Sedangkan sebanyak $37.39 \%$ dari 176 jawaban $(22 \times 8)$ subjek dapat menyelesaikan soal level 5 . Sedangkan pada soal level 6 sebanyak $16 \%$ dari 44 jawaban $(22 \times 2)$ subjek

Tabel 1. Hasil Angket Kemampuan Matematika

\begin{tabular}{clc}
\hline No & Kemampuan Matematika yang Dilibatkan & $\begin{array}{c}\text { Persentase } \\
\text { Respon Siswa }\end{array}$ \\
\hline 1 & $\begin{array}{l}\text { Membuat model matematika sendiri, seperti membuat persamaan matema- } \\
\text { tika, membuat pola barisan bilangan dan sejenisnya }\end{array}$ & $36.36 \%$ \\
2 & Menuliskan jawaban seperti membuat perhitungan dengan runtut & $18.18 \%$ \\
3 & $\begin{array}{l}\text { Membuat model gambar, tabel, grafik, dan sejenisnya untuk membantu } \\
\text { menemukan jawaban }\end{array}$ & $18.18 \%$ \\
5 & Memilih dan membandingkan strategi-strategi untuk menemukan jawaban & $72.74 \%$ \\
6 & $\begin{array}{l}\text { Bernalar dengan mengaitkan informasi-informasi pada soal dengan pengala- } \\
\text { man yang sudah ada }\end{array}$ & $50 \%$ \\
7 & $\begin{array}{l}\text { Menggunakan rumus-rumus matematika tertentu untuk memperoleh jawa- } \\
\text { ban }\end{array}$ & $90.91 \%$ \\
\hline
\end{tabular}


dapat menyelesaikan soal. Dari hasil angket di dapat bahwa siswa rendah dalam mengkomunikasi dan merepresentasi matematika kedalam konteks. Tabel 1 merupakan hasil angket kemampuan dasar matematika siswa.

Berdasarkan tabel 1 diketahui semua jenis kemampuan matematika digunakan oleh siswa dalam menyelesaikan soal prototipe 3 . Diantara kemampuan tersebut, kemampuan bernalar dengan mengaitkan informasi pada soal dengan pengalaman yang sudah ada atau yang dalam KDM disebut sebagai penalaran dan argumentasi, diakui oleh paling banyak siswa $(90,91 \%)$ digunakan dalam menyelesaikan soal Sementara itu, siswa menggunakan kemampuan komunikasi dan representasi masing-masing sama $18.18 \%$. siswa mengakuimelibatkan kemampuan menuliskan jawaban seperti membuat perhitungan denganruntut (komunikasi) dan membuat/memanfaatkan gambar, tabel grafik, dansejenisnya (representasi) dalam menyelesaikan soal. Persentase respon untuk komunikasi yang rendah ini didukung oleh pernyataan siswa yang memang merasa kesulitan dalam proses mengerjakannya. Menurut siswa, penyelesaian soal dengan cara ini dianggap sebagai hal yang aneh karena tidak terbiasa.

Dari 330 jawaban $(22 \times 15)$ yang peneliti analisis hanya $20,45 \%$ siswa dapat menjawab benar, hal ini semakin mendukung fakta bahwa rata-rata siswa Indonesia hanya bisa mengerjakan soal model PISA level 3 kebawah (OECD, 2013).

Berdasarkan hasil uji field test ratarata persentase pencapaian siswa kategori menerapkan menempati posisi terendah, yaitu $29.88 \%$. Jika dibandingkan dengan kedua kategori lainnya, angka ini hampir setengah kali lebih rendah dari angka keduanya dimana pada kategori merumuskan dan menafsirkan secara berturut-turut menunjukkan rata-rata persentase $57 \%$ dan $44.06 \%$.

Dengan demikian, dapat disimpulkan bahwa soal model PISA yang peneliti kembangkan ini menuntut siswa lebih banyak dalam menggunakan konsep, fakta, prosedur, dan penalaran untuk memecah- kan masalah yang telah dirumuskan untuk memperoleh kesimpulan matematis lebih rendah dari pada kemampuan mereka dalam menerjemahkan masalah dunia nyata ke dalam struktur dan representasi matematika serta membuat penafsiran dari hasil matematika yang diperoleh kembali ke dunia nyata

Sedangkan semua level yang peneliti kembangkan dapat diselesaikan oleh siswa dengan masing-masing level 4 rata-rata $39.50 \%$ subjek mendapatkan skor maksimum, level 5 rata-rata sebanyak $37.39 \%$, dan sebanyak $16 \%$ rata-rata mencapai level 6. Ini berbeda dengan hasil PISA pada tahun 2012 bahwa siswa Indonesia hanya sampai level 3 saja dan tidak ada satupun siswa yang mampu memcapai level 5 dan 6 (OECD, 2013).

Dari komentar siswa bahwa siswa beIum terbiasa dalam mengerjakan soal-soal matematika model PISA. Sebagian besar siswa tidak mampu melibatkan semua Kemampuan Dasar Matematika (KDM). Seperti pertanyaan soal no 1 konteks kain tapis Lampung, sebanyak 5 subjek mampu menjawab dengan tepat, 2 orang mampu menjawab tetapi tidak sampai hasil akhir, dan 15 subjek tidak mampu menjawab pertanyaan.

\section{Soal no. 1}

Soal no 1 sebanyak ketujuh subjek dapat menjawab dengan tepat dengan mengkomunikasikan informasi untuk memecahkan permasalahan, mampu menalar dengan menggabungkan konsep luas dan pola bilangan, dan mampu menerjemahkan luas kain subjek dalam menjawab pertanyaan ini disebabkan subjek hanya mampu melibatkan beberapa KDM.

Seperti subjek dibawah S-15 tidak mampu mengkomunikasikan informasi dalam menalar untuk memecahkan permasalahan, sehingga akan salah dalam merepresentasikan permasalahan. begitu juga dengan S-19 tidak mampu mengkomunikasikan informasi sehingga akan salah dalam melibatkan KDM yang lainnya. 


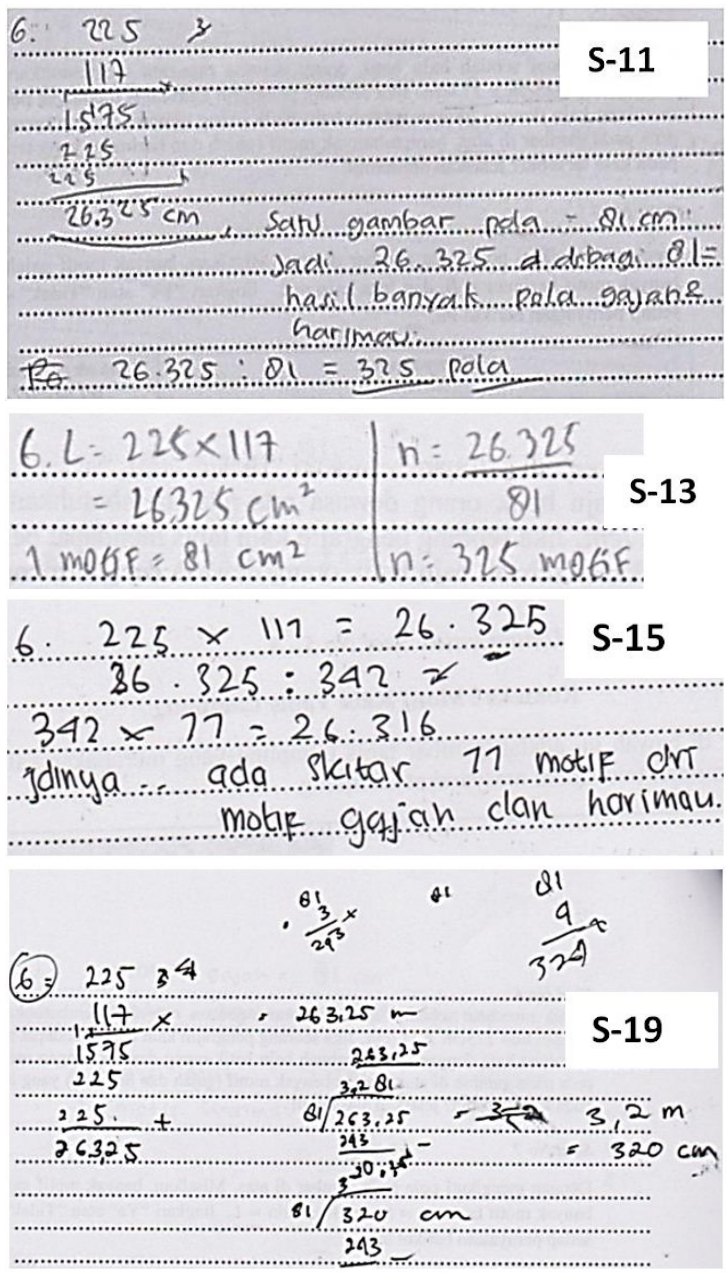

Gambar 6. Jawaban no 1 (S-11, S-13, S-15 dan S-19)

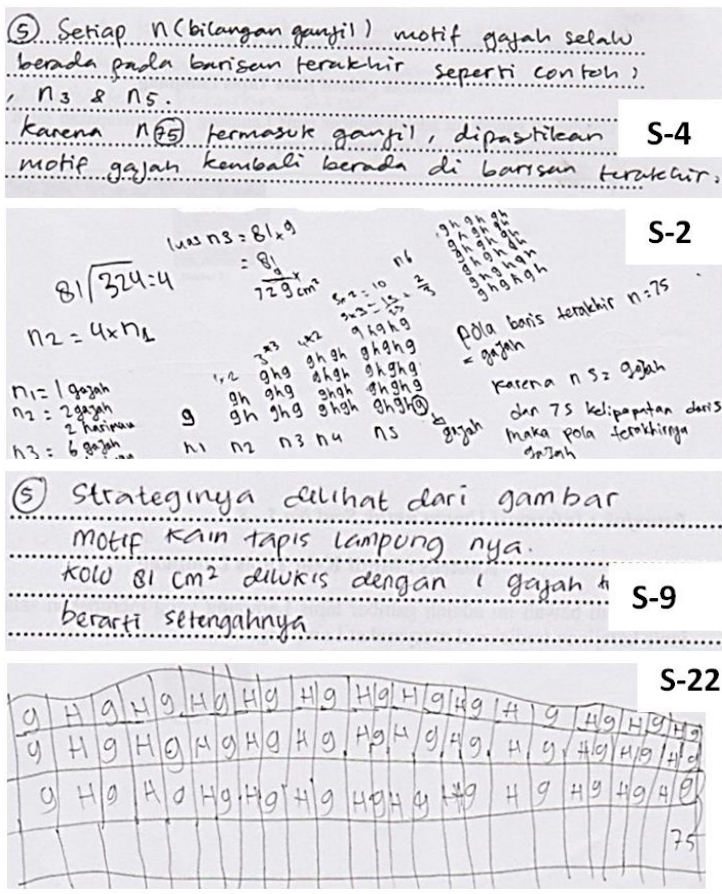

Gambar 7. Jawaban no 10 (S-9, S-2, S-4 dan S-22)

\section{Soal no 2}

Dalam pertanyaan ini sebanyak 7 subjek dapat menjawab dengan tepat mereka memunculkan kemampuan literasi berbeda seperti jawaban yang dapat dilihat pada Gambar 7.

S-22 menggunakan strategi pemecahan masalah dengan menggunakan tabel dari pola 1 sampai pola 75, begitu juga dengan S-2 menentukan pola susunan motif ke-75 dengan menggunakan skema dari pola 1 . berbeda dengan S-4 memecahkan masalah dengan menalar pola yang ditanya dengan mengkomunikasikan informasi dengan membuat representasi langsung dari permasalahan dengan mengaitkan matematisasinya dengan menerjemahkan pola susunan motif dalam membuat kesimpulan. Kesalahan subjek dalam menjawab pertanyaan ini subjek tidak mampu melibatkan semua KDM, seperti S-g kesalahan pertama tidak mampu mengkomunikasikan informasi untuk melibatkan kemampuan matematisasinya dalam menerjemahkan susunan motif dalam membuat kesimpulan, dan tidak mampu menalar sesuai permasalahan, sehingga akan salah dalam pemecahan masalah dan representasi permasalahan.

\section{Soal no 3}

Pada soal no 9 konteks Anak Gunung Krakatau ini siswa kesulitan dalam menjawab pertanyaan, ini disebabkan level soal yang tinggi yaitu level 6 dalam PISA, selain itu subjek tidak mampu dalam melibatkan semua KDM. Dari 22 subjek penelitian terdapat 2 subjek dapat menjawab benar, 4 subjek mampu menjawab tetapi tidak sampai pada hasil dalam menentukan banyak motif, sehingga mampu menginterpretasikan dalam menghitung banyak motif. Kesalahan akhir, dan 16 siswa tidak mampu dalam menjawab pertanyaan.

Kesalahan subjek dalam menjawab pertanyaan terletak pada melibatkan kemampuan KDM.

S-4 disini mampu memahami teks dan menalar dengan menggabungkan informasi konteks serta mampu menerjemahkan dan menghitung permasalahan konteks kedalam bentuk perhitungan matematis. sedangkan S-3 mampu menalar dengan mengkomuni- 
kasikan informasi konteks kedalam bentuk matematis tetapi tidak mampu membuat perhitungan secara matematis dengan tepat. begitu juga dengan $\mathrm{S}-15$ tidak mampu menghitung secara matematis sesuai dengan permasalahan.

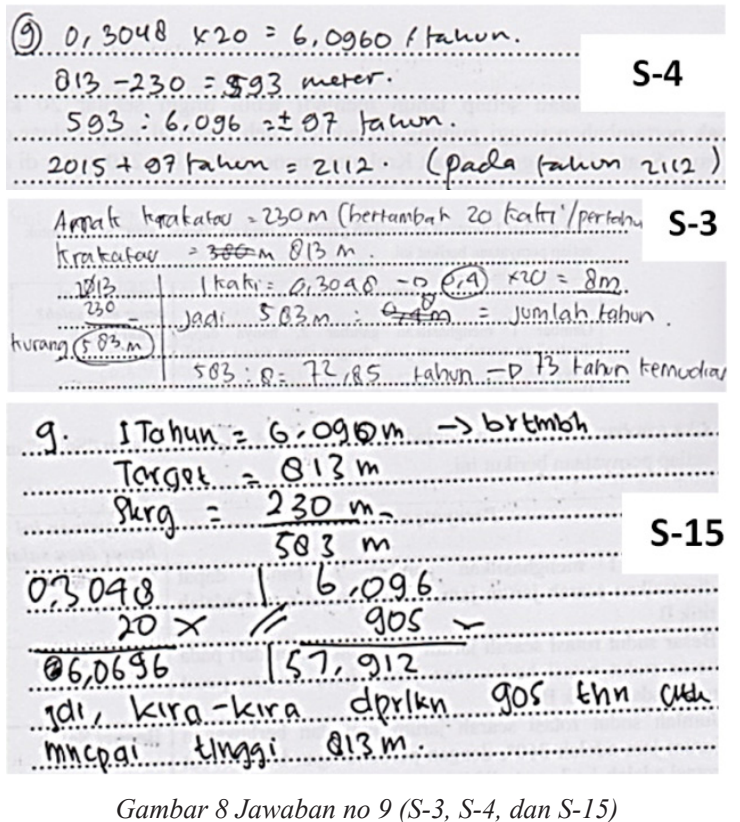

\section{SIMPULAN}

Dari hasil penelitian dan pembahasan bahwa siswa Lampung kemampuan literasi matematikanya masih rendah dalam menyelesaikan soal-soal model PISA level 4, 5, 6 . ini terlihat dari hasil penelitian didapatkan $20,45 \%$ dari $330(22 \times 15)$ butir jawaban yang dianalisis yang teridentifikasi sebagai jawaban benar. dari analisis komentar siswa pada angket bahwa siswa masih kesulitan dalam mengkomunikasikan dan merepresentasikan permasalahan kedalam konteks.

Soal-soal menggunakan konteks mempermudah siswa dalam mensituasikan matematika kedalam konteks sehingga akan membantu siswa dalam menggunakan kemampuan literasi dalam menjawab soal, dan dapat menantang pola berpikir matematis siswa. Ini terlihat bahwa siswa bisa menyeles- aikan soal level 5 dan 6 berturut-turut 37.39 \% dan 16\% berbeda dengan hasil PISA 2012 yang menyatakan bahwa untuk soal PISA level 5 dan level 6, tak satu pun siswa Indonesia mampu menjawab (OECD, 2013).

Diharapkan bagi guru khususnya guru lampung untuk menggunakan soal-soal PISA dalam pembelajaran dan mendesain soalsoal menggunakan konteks yang berkaitan dengan daerah siswa, dan bagi para peneliti selanjutnya dapat mengembangkan soalsoal matematika khusunya soal model PISA menggunakan konteks lain atau daerah lain sesuai dengan subjek penelitian.

\section{DAFTAR PUSTAKA}

Kadir \& Masi, L. (2013). Penggunaan konteks dalam pembelajaran matematika untuk meningkatkan keterampilan sosial siswa SMP. KNPM V (hal. 786-796). Kendari: Himpunan Matematika Indonesia.

Kemendikbud. (2011). Survei International PISA. Dipetik Oktober 4, 2014, dari http: //litbang.kemdikbud. go.id/index.php/survei-internasional-pisa

Lutfianto, M., Zulkardi, \& Hartono, Y. (2013). Unfinished Student Answer In PISA Mathematics Contextual Problem. Journal on Mathematics Education (IndoMS-JME), 4(2), 201-208.

NCES. (2004). International Outcomes of Learning in Mathematics Literacy and Problem Solving; PISA 2003 results from the U.S. perspective, diakses dari http://nces.ed .gov / pubs 2005 / 2005003. pdf pada 3 Oktober 2014.

OECD. (2013). PISA 2012 Assessment and Analytical Framework: Mathematics, Reading, Science, Problem Solving and Financial Literacy. Paris: OECD Publishing

OECD. (2013). PISA 2015 Mathematics Framework. Paris: OECD Publishing.

Shiel, G., Perkins, R., Close, S., \& Oldham, E. (2007). PISA Mathematics: a teacher's guide. Dublin: Stationery Office

Stacey, K. (2014). The PISA view of mathematical literacy in Indonesia.Journal on Mathematics Education, 2(02), 95-126.

Tessmer, M. (1993). Planning and conducting formative evaluations: Improving the quality of education and training. London: Kogan Page.

Zulkardi. (2006). Formative Evaluation: What, Why, When, and How, diakses dari http://www.reocities.com/zulkardi/books.html pada 20 Agustus 2013. 